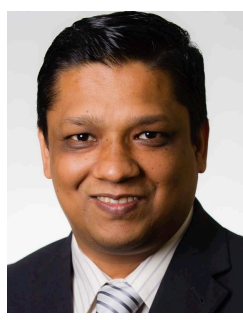

\title{
PROPOSED REDD+ PROJECT FOR THE SUNDARBANS: LEGAL AND INSTITUTIONAL ISSUES
}

\author{
Dr Saiful Karim \\ Lecturer, School of Law \\ Faculty of Law \\ Queensland University of Technology \\ Brisbane, Australia
}

\begin{abstract}
Sundarbans, a Ramsar and World Heritage site, is the largest single block of tidal halophytic mangrove forest in the world covering parts of Bangladesh and India. Natural mangroves were very common along the entire coast of Bangladesh. However, all other natural mangrove forests, including the Chakaria Sundarbans with 21,000 hectares of mangrove, have been cleared for shrimp cultivation. Against this backdrop, the Forest Department of Bangladesh has developed project design documents for a project called 'Collaborative REDD+ Improved Forest Management (IFM) Sundarbans Project' (CRISP) to save the only remaining natural mangrove forest of the country. This project, involving conservation of 412,000 ha of natural mangrove forests, is expected to generate, over a 30-year period, a total emissions reduction of about 6.4 million tons of $\mathrm{CO}_{2}$. However, the successful implementation of this project involves a number of critical legal and institutional issues. It may involve complex legal issues such as forest ownership, forest use rights, rights of local people and carbon rights. It may also involve institutional reforms. Ensuring good governance of the proposed project is very vital considering the failure of the Asian Development Bank (ADB) funded and Bangladesh Forest Department managed 'Sundarbans Biodiversity Conservation Project'. Considering this previous experience, this paper suggests that a comprehensive legal and institutional review and reform is needed for the successful implementation of the proposed CRISP project. This paper argues that without ensuring local people's rights and their participation, no project can be successful in the Sundarbans. Moreover, corruption of local and international officials may be a serious hurdle in the successful implementation of the project.
\end{abstract}

\section{Introduction}

The Sundarbans is the largest single block of tidal halophytic mangrove forest in the world covering parts of Bangladesh and India. ${ }^{1}$ Spreading out over about one million hectares of land in Bangladesh and India, this mangrove forest is located in the estuary of the river Ganges. ${ }^{2}$ Roughly 60 per cent of the Sundarbans fall in Bangladesh, spaning to an area of $6017 \mathrm{~km}^{2}$ sharing both land and water body that forms ideal mangrove ecosystem. The Sundarbans ecosystem supports large number of commercially and ecologically valuable marine and coastal species, and hosts one of the richest natural gene pools for fauna and flora in the world. ${ }^{3}$ This mangrove is habitat for about 42 species of mammals, 300 species of birds, 35 reptiles, and 8 amphibian species including the largest population of the Bengal Tiger. ${ }^{4}$ The livelihoods of over 3.5 million people from the surrounding areas directly or indirectly depend on the Sundarbans. ${ }^{5}$

Although itself seriously vulnerable to climate change, ${ }^{6}$ the Sundarbans has great potential to generate significant greenhouse gases emissions reduction. The Forest Department of Bangladesh has developed

\footnotetext{
1 M Enamul Hoq, 'An Analysis of Fisheries Exploitation and Management Practices in Sundarbans Mangrove Ecosystem, Bangladesh’ (2007) 50 Ocean \& Coastal Management 411.

2 Ibid.

3 M Shafi, N Islam and Albrecht Gnauck, 'Threats to the Sundarbans Mangrove Wetland Ecosystems from Transboundary Water Allocation in the Ganges Basin: A Preliminary Problem Analysis' (2009) International Journal of Ecological Economics \& Statistics 64, 65.

4 Ibid.

5 Hoq, above $\mathrm{n} 1$.

6 Syed Azizul Haq, 'Impact of Climate Change on "Sundarbans”, The Largest Mangrove Forest: Ways Forward' (paper presented at the 18th Commonwealth Forestry Conference, Edinburgh, Scotland, UK, 28 June - 2 July 2010 ); Colby Loucks et al, 'Sea Level Rise and Tigers: Predicted Impacts to Bangladesh's Sundarbans Mangroves: A letter' (2010) 98 Climatic Change 291; Nesar Ahmed, Anna Occhipinti-Ambrogi and James F Muir, 'The Impact of Climate Change on
} 
project design documents for a project called 'Collaborate REDD+ Improved Forest Management (IFM) Sundarbans Project (CRISP)' to save the only remaining natural mangrove forest of the country. ${ }^{7}$ The CRISP project involves conservation of 412,000 hectares of natural mangrove forests and is expected to generate total emissions reduction of about 6.4 million tons of $\mathrm{CO}_{2}$ emissions over a 30 -year period. ${ }^{8}$

A comprehensive legal and institutional review and reform is needed for the successful implementation of the proposed CRISP project. The implementation of the proposed project may involve a number of legal issues including land ownership (whether they are owned by the government and if so, what are the livelihood rights of people in such forests), forest ownership and use rights, customary rights, community-based forest rights and carbon rights. Another important issue is corruption and good governance. The Asian Development Bank (ADB), in its completion report of a previously-undertaken conservation project, namely the Sunderbans Biodiversity Conservation Project, stated that the 'weakness in its implementation arrangement' as the main reason for the poor performance of the project. ${ }^{9}$ This paper aims to present a brief overview of some of these issues. This paper argues that without ensuring local people's rights and their participation, no project can be successful in the Sundarbans. Moreover, corruption of local and international officials may be a serious hurdle in the successful implementation of the project.

\section{Aims and objectives of the CRISP project}

The CRISP project aims to avoid deforestation and degradation, and to introduce improved forest management activities in the Sunderbans. ${ }^{10}$ The main objectives of the project are to achieve carbon sequestration as well as livelihoods improvements through community participation in forestry activities and conservation of flora and fauna species through measures including habitat protection and improvement. ${ }^{11}$ The emissions reductions will be achieved through avoided deforestation and forest degradation. The project has three main objectives: climate mitigation; assisting local communities by providing alternative livelihood options and conservation-linked value chain development to reduce forest dependency for daily needs; and conserve the habitat of several endangered species. ${ }^{12}$ The project will ensure improved forest management by introducing management zoning, imposing a permanent ban on commercial harvesting, and controlling deforestation and forests degradation. ${ }^{13}$ All these project activities may have an impact on the livelihood of local people. To determine the legal and institutional issues relating to the implementation of the project, it is pertinent to examine the existing legal status of the Sundarbans.

\section{Legal status of the Sundarbans}

Before initiating a REDD+ project for the Sundarbans, it is pertinent to identity relevant laws governing this mangrove forest and the legal status of the forest. The Sundarbans is, undoubtedly, a place of international and national significance, hence both international and national law determine its legal status. The mangrove is under a different protected area regime. This part briefly discusses the international and national legal status.

\section{International law}

The Sundarbans has considerable international legal status. It is both a Ramsar ${ }^{14}$ and a World Heritage ${ }^{15}$ site. The Convention on Wetlands of International Importance especially as Waterfowl Habitat ('Ramsar Convention'), was adopted in 1971 in the Iranian city of Ramsar in 1971, is the only global environmental treaty that deals with a particular ecosystem. The Ramsar Convention obligates each Contracting Party to

Prawn Post Larvae Fishing in Coastal Bangladesh: Socio Economic and Ecological Perspectives’ (2013) 39 Marine Policy 224; Islam and Gnauck, above n 3.

${ }^{7}$ Forest Department, Project Concept Note: Collaborative REDD+IFM Sundarbans Project (CRISP), (Forest Department, 2011).

${ }^{8}$ UN-REDD Programme, Bangladesh REDD+ Readiness Roadmap (UN-REDD Programme, 2012) 39.

${ }^{9}$ Asian Development Bank, Project Completion Report Bangladesh: Sundarbans Biodiversity Conservation Project (Asian Development Bank, 2008).

${ }^{10}$ Forest Department, above n 7.

11 Ibid.

12 Ibid.

13 Ibid.

${ }^{14}$ Convention on Wetlands of International Importance Especially as Waterfowl Habitat, opened for signature 2 February 1971, 996 UNTS 245 (entered into force 21 December 1975) ('Ramsar Convention').

${ }^{15}$ Convention Concerning the Protection of the World Cultural and Natural Heritage, opened for signature 16 November 1972, 1037 UNTS 151 (entered into force 17 December 1975) ('World Heritage Convention’). 
designate suitable wetlands within its territory for inclusion in a List of Wetlands of International Importance. The Ramsar Convention imposes a number of obligations on state parties for conservation of Wetlands. They are also required to formulate and implement their national planning so as to promote the conservation of the wetlands included in the List, and, as far as possible, the wise use of wetlands in their territory. The Sundarbans was first designated for the Ramsar List in May 1992. ${ }^{16}$ In 2003, the Bangladeshi Government enlarged the Ramsar site area from 596,000 to 601,700 hectares and changed the name of site to 'Sundarbans Reserved Forest'. ${ }^{17}$

The World Herigate Convention ('WHC')is arguably the most important international legal instrument for the protection of heritage. ${ }^{18}$ Generally, heritage can be defined as that which is 'worth preserving and sharing with present and future generations. ${ }^{19}$ The WHC protects cultural or natural heritage that are of outstanding interest and need to be preserved as part of the world heritage for mankind as a whole. A total of 139,500 hectare area, including three wildlife sanctuaries within the Sundarbans, has been included in the World Heritage List in 1997. The WHC recognises that the primary duty belongs to the concerned State for ensuring the protection and conservation of the cultural and natural heritage situated on its territory. It has obligations to undertake all it can to this end, to the utmost of its own resources and, where appropriate, with any international assistance and co-operation. The REDD+ initiative may be a mechanism for international assistance and there is a need for a joint initiative between UNESCO and UNEP to determine the scope of cooperation where a world heritage site like the Sundarbans has REDD+ potential.

\section{National law}

The Sundarbans has a long history of governance under forest law, which started in the colonial era. Historically, forests in Bangladesh were managed by the local people whose livelihood and survival depended upon them. Forests management was mainly governed by local cultural and economic traditions. However, the Mughal Government (1526-1756) began to change this practice by providing incentives to undertake agricultural activities within the Sundarbans. ${ }^{20}$ This exploitive practice was further intensified under British colonial rule from 1756 to the mid-1800s, and for more than 100 years, the needs and greed of the British Empire guided the management of Bangladesh forests. ${ }^{21}$ In 1793, the colonial government enacted the Permanent Settlement Act to introduce the Zamindary (landlord) system. Through this system, the Zamindars became owners of the land as well as the administrators of all property right. The Zamindars were entrusted with right to accumulate fixed revenue from the tenants and they had to pay fixed revenue to the colonial government. The main motive of the British colonial ruler was to ensure revenue from the land. This system had a far-reaching impact on the Sundarbans. To increase rent collection, local Zamindars brought in ethnic Munda people from Bihar in the Sundarbans to clear the forest for cultivation. ${ }^{22}$ This practice contributed to significant forest reduction of forest in the Sundarbans.

The British Indian Government adopted the Forest Charter of 1855 as a first attempt of forest governance making forest produce state property and strictly regulating timber trade. ${ }^{23}$ The colonial government enacted the Indian Forest Act 1865 as the first ever forest legislation. This Act gave the government power to issue notifications appropriating any land covered with trees after considering the existing rights of local people. However, considering the socio-economic condition of local people in that time, it was all most impossible for them to vindicate their legal rights. The Indian Forest Act 1865 was replaced by the Indian Forest Act of 1878 . The new law abolished all the privileges and rights that were not explicitly granted by the state and terminated "centuries-old system of rights and privileges for forest-inhabiting and forestdependent communities. ${ }^{24}$ This Act changed the common property of local people into state property and considered the rights of local people over forest lands and produce as concessions. It divided forests into three types: reserved, protected and village forests. The Act established full control and rights of state over reserved forests. The 1878 Act was replaced by the Indian Forest Act 1927. The new law largely re-

\footnotetext{
${ }^{16}$ Bangladesh enlarges Sundarbans Ramsar site < http: / / www.ramsar.org/cda/en/ramsar-media-sites-bangladeshenlarges/main/ramsar/1-25-34\%5E18490_4000_0_>.

${ }^{18}$ Erika J. Techera, 'International Cultural Heritage Law' in Shawkat Alam et al (eds), Routledge Handbook of International Environmental Law (London: Routledge) 407,410

${ }^{19}$ Graeme Aplin, Heritage: Identification, Conservation, and Management (Oxford University Press, 2002 ) 4.

${ }^{20}$ Anjan Kumer Dev Roy, Khorshed Alam and Jeff Gow, 'A Review of the Role of Property Rights and Forest Policies in the Management of the Sundarbans Mangrove Forest in Bangladesh' (2012) 15 Forest Policy and Economics $46,48$.

21 Ibid.

22 Ibid.

${ }^{23}$ Jo Lawbuary, Reclaiming the Forests? People's Participation in Forest Management, East India (Thesis Submitted in partial fulfilment of BSc. (Hons.) Human Environmental Science, King's College, London April 16 1999). 
tained the structure of the previous Act. The Forest Act 1927 is still applicable in Bangladesh with a number of amendments.

A large portion of the Sundarbans mangrove forests was declared as reserved forests in 1875 and the remaining portions of forests were declared as reserve forest in the following year. ${ }^{25}$ The Sudarbans is still a reserved forest under the Forest Act 1927. In addition, the government established three wildlife sanctuaries in 1977 under the Bangladesh Wildlife (Preservation) Order 1973 ('P O 23 of 1973'). This Order was replaced by the Wildlife (Preservation \& Security) Acts 2012. The three wildlife sanctuaries established in 1977 will retain their status under the new law.

The Bangladesh Environment Conservation Act 1995 is also relevant for the Sundarbans. The Act provides provision for the declaration of ecologically critical areas and also deals with direct or indirect damage to the ecosystem. Under section 5 of the Environment Conservation Act 1995, the government has been entrusted with the responsibility of declaring, by notification in the official Gazette, an area as Ecologically Critical Area (ECA) if it is satisfied that, due to degradation of the environment, the ecosystem of that area has reached or is threatened to reach a critical state. Pursuant to sub-section (2) of section 5 of the Act, once an area is declared an ECA, the Government shall also specify, by notification in official Gazette, the operations/processes that shall not be carried out or initiated in the ECA. Acting on section 5 of the Act, the Government has declared a 10-kilometre area around the reserved forest of the Sundarbans as an ECA. The Bovernment, by another notification ,withdrew the ECA declaration of some areas on the grounds that these areas are reserve forests.

Despite having the special status under different national and international legal instruments, the Sundarbans is facing serious degradation. There are serious legal and institutional issues behind this failure of governance. The next part briefly discuses some of these issues.

\section{Legal and institutional issues related to proposed REDD+ projects}

Implementation of a REDD+ project may involve a number of legal issues including, inter alia, ownership of land, forest and carbon; participation; balancing of rights and interests; and benefit sharing. ${ }^{26}$

Normally forest ownership is associated with land ownership. ${ }^{27}$ There may be a high investment risk for REDD+ project where land ownership challenges exist. ${ }^{28}$ According to the Stern Review:

At a national level, defining property rights to forestland, and determining the rights and responsibilities of landowners, communities and loggers, is key to effective forest management. This should involve local communities, respect informal rights and social structures, work with development goals and reinforce the process of protecting the forests. ${ }^{29}$

Ownership of land and forest may, arguably, not be a serious issue for the Sundarbans because of its longstanding status as a reserved forest. In the project documents, the Forest Department claimed the following:

The sole owner and manager of the project area is the Forest Department [FD] of the Government of Bangladesh (GOB). The department is empowered by the GOB through relevant Forest Acts and Rules. So the access right to the project area and resource collection is controlled by the $\mathrm{FD}$ and requires their permission. There are no current, ongoing, or recent disputes over the project area, which has been under protected status by the government since 1875 . The land category of the project areas is Reserved Forest land, with the legal title of land ownership held by the Government of Bangladesh through the FD ... Thus, land tenure is clear, and rather than land disputes being the greatest source of these conflicts, forest resources and the FD's attempts at preventing their exploitation through poaching and illegal harvesting are. ${ }^{30}$

\footnotetext{
${ }^{25}$ Laskar Muqsudur Rahman, The Sundarbans: A Unique Wilderness of the World <http://www.fs.fed.us/rm/pubs/rmrs_p015_2/rmrs_p015_2_143_148.pdf>.

${ }^{26}$ Annalisa Savaresi and Elisa Morgera 'Ownership of Land, Forest and Carbon' in John Costenbader (ed), Legal Frameworks for REDD: Design and Implementation at the National Level (IUCN, 2009) 15.

${ }^{27}$ Ibid.

${ }^{28}$ Ibid.

${ }^{29}$ Nicholas Stern, Stern Review: The Economics of Climate Change < http://www.hmtreasury.gov.uk/d/Executive_Summary.pdf >

${ }^{30}$ Forest Department, above n 7.
} 
The legal title to all of the project area rests with the state and there are no tenure disputes, mainly due to the longstanding history of government ownership going back to British colonial times in the $19^{\text {th }}$ century. ${ }^{31}$ Access and use of the Sundarban resources is entirely dependent on permits issued by the Forest Department.

As stated earlier, in the late $19^{\text {th }}$ century, the colonial government imposed state ownership on the Sundarbans and other forests of the country through promulgation of the Forest Act, largely ignoring the rights of the forest dependant people. There is no doubt that the government is the landowner in the Sundarbans. However, ownership of the forest and forest land is part of the story only. Due to its unique and immovable nature, land may be subject to rights of person or persons other that the owner. One such rights is usufructuary right. Local people may have usufructuary rights over the Sudarbans, such as right of collection of forest products. A considerable number of local communities are dependent on the Sundarbans for their livelihoods including bawalis (wood cutters), jele (fisher folk), mouals (honey collectors) and chunari (snail and oyster collectors) who live at the Sundarbans impact zone. ${ }^{32}$ However, under the current forest legal system, recognition of rights of these communities is conditional upon permission of the Forest Department under statutory law. However, this strong control of government does not necessarily enhance the protection of the Sundarbans. The objectives of the Forest Act, enacted in the colonial era, were mainly directed towards consolidate the law relating to forests, the transit of forest produce and the duty leviable on timber and other forest-produce. Revenue generation is the main objective of this law and it treated the 'traditional forest rights' as 'adverse claims' and called forest dwellers 'ignorant people'. ${ }^{33}$ It has been stated in Bangladesh REDD+ Readiness Road Map that:

\begin{abstract}
In law, traditional rights and rights emerging from prescription or adverse possession had been legally recognized. Long-term possession creates rights by prescription. According to the Limitation Act, 1908, rights exercised or enjoyed uninterrupted for twenty years, on any private property, or sixty years in case of government property create a legal right. In light of the provisions of the Limitation Act, 1908 one may rightfully assert that before the vesting of any forest in the government, if the same was a part of a private estate of a landlord, then a proof of uninterrupted possession or enjoyment for twenty years would be required by law. In cases where forests have been the khas property of the State, sixty years would be the period for acquiring titles. ${ }^{34}$
\end{abstract}

This statement may give a wrong impression that if forest dwellers are exercising their rights over a reserved forest for 60 years they may claim a legal right. However, it is not possible in the case of reserved forest. According to section 5 of the Forest Act 1927, after the issuance of a notification under section 4 publishing the government intention to declare an area as reserved forest, no right shall be acquired in or over the land comprised in such notification, except by succession or under a grant or contract in writing made or entered into by or on behalf of the Government or some person in whom such right was vested when the notification was issued. Again according to section 22 of the of Forest Act, no right of any description shall be acquired in or over a reserved forest except by succession or under a grant or contract in writing made by or on behalf of the government or some person in whom such right was vested when the notification under section 20 was issued declaring a forest as reserved forest. It is a long-standing principle of law in the common law countries that when two statutes are in conflict, the latest in time prevails. ${ }^{35}$ Moreover, a special Act prevails over the general Act in the case of inconsistency. Using Limitation Act of 1908 does not provide any significant prospect for protection of the customary rights of forest dwellers. In fact, the project document of the proposed CRISP project is right in holding that the access right to the project area and resource collection is controlled by the Forest Department and requires their permission. ${ }^{36}$

Due to the declaration of the Sudarbans as a reserved forest in 1885, the scope for protecting customary rights of local people is very limited. However, strict state ownership does not necessarily ensure the conservation of the Sundarbans against exploitive practices. Many small and large industries have been established in south-western Bangladesh based on raw materials form the Sudarbans without considering the adverse consequence to the forest, and this industrial development failed to consider the need of mil-

\footnotetext{
${ }^{31}$ Ibid.

32 Dewan Muhammad Humayun Kabir and Jakir Hossain, 'Resuscitating the Sundarbans: Customary Use of Biodiversity \& Traditional Culture Practices In Bangladesh’ (Unnayan Onneshan-The Innovators, 2008) 17.

33 S Rizwana Hasan, Conservative Forest Act cannot conserve forests,

<http://www.thedailystar.net/law/2008/06/01/index.htm > accessed 2 February 2013.

${ }^{34}$ UN-REDD Programme, above $\mathrm{n} 8$.

${ }^{35}$ Quintin Johnstone, ‘An Evaluation of the Rules of Statutory Interpretation' (1954-1955) 3 University of Kansas Law Review $1,3$.

${ }^{36}$ Forest Department, above $\mathrm{n} 7$.
} 
lions of forest dwellers but encourages illegal logging and overharvesting to fulfil the demand of the industries. $^{37}$

Moreover, the absolute power under the Forest Act 1927 has already resulted in a corrupt Forest Department, and the Sundarbans is being destroyed because of rampant corruption. ${ }^{38}$ The Bangladesh branch of the Berlin-based watchdog Transparency International has conducted a study on corruption in the Forestry Sector of Bangladesh that revealed a systematic practice of corruption in that sector. The study showed that corruption is a very common phenomenon with regard to issuing licenses for logging and transporting logs, forest land grabbing, illegal collection of honey, fish and other forest products and resources, abuse and misuse of funds and resources in project implementation. Forest department personnel have direct involvement in the corrupt practices. ${ }^{39}$ Corruption of government officials and vested interest quarters is one of the main factors in the destruction of forests. However, Forest Department officials routinely blame poor local people for the destruction of the forest. However, the role of poor forest dwellers is very marginal in the destruction of forest. As observed by a local person who has been caught up in 17 cases filed by the Forest Department:

Do you think that we forest people steal wood from the forest? Maybe some of us 'steal' because the FD [Forest Department] officials do not allow permits to enter the forest without offering them bribes. But they do not file cases against the big trawlers that come from the cities and cut down all the trees either matured or not. These destructive people don't fall in a case, because they have money and linkage with the FD officials. (Gazi Ebaet Sheikh) ${ }^{40}$

The report of Transparency International also claimed that bribery is very common for the appointment of top-level jobs in the Forest Department of Bangladesh. The report also mentioned that a former Chief Conservator of Forest (the highest post of Forest Department) paid US\$161,000 as bribe to get the post in an auction - this type of auction is very common for the top level jobs in Forest Department! ${ }^{41}$

As observed earlier, corruption and lack of good governance in the process of planning and implementation significantly curtailed the effectiveness of previously undertaken projects for the conservation of the Sudarbans. This issue can be explained by a previously-initiated project called the Sundarbans Biodiversity Conservation Project, partially funded by the ADB. The goal of this project was to secure the integrity of the environment and biodiversity of the Sundarbans. ${ }^{42}$ The project aimed to develop a system for sustainable management and conservation of the Sundarbans and the surrounding impact and marine zones. ${ }^{43}$ Although this $\$ \$ 77.3$ million project was scheduled to be implemented between 1999 and 2006, the Forest Department and the ADB, suspended the project in September $2003 .{ }^{44}$ The ADB admitted in its project completion report that the project was unsuccessful and it has failed to achieve its stated goals and objectives. $^{45}$

Unfortunately, even international organisations such as the ADB may also be involved in corruption while planning and implementing this kind of projects, making the situation more problematic. The ADB or similar organisations may not be involved in bribery, but their corruption is more severe. For example, the $A D B$ claimed that the Sundarban Biodiversity Conservation Project has been failed due to the failure of Bangladeshi authorities. ${ }^{46}$ However, an independent research by a non-governmental organisation showed that the project failed mainly due to ADB corruption. ${ }^{47}$ For example 53 per cent of the total budget of the Sundarbans Biodiversity Project was allocated for foreign consultancy services, 11 per cent for local consultants, 6 per cent for international travel and 2 per cent for local travel. ${ }^{48}$ What remains for improving livelihood of local people or conserving the forest? The financing agencies directly handled this consultancy

\footnotetext{
${ }^{37}$ Roy et al., above $\mathrm{n} 20$.

${ }^{38}$ AFP, Corruption Killing Bangladesh Forests: Watchdog <http://afp.google.com/article/ALeqM5jLR9PkDKZiQcLpgiyjimb5uC5MAQ>.

${ }^{39}$ Transparency International Bangladesh, Annual Report 2008 (TIB, 2008) 19.

${ }^{40}$ Jakir Hossain and Kushal Roy, Deserting the Sundarbans: Local People's Perspective on ADB-GEF-Netherlands Funded Sundarbans Biodiversity Conservation Project (Unnayan Onneshan, 20087) 31.

${ }^{41}$ AFP, above $\mathrm{n} 38$.

${ }^{42}$ Asian Development Bank, above $\mathrm{n} 9$.

${ }^{43}$ Ibid.

${ }^{44}$ Hossain and Roy, above $\mathrm{n} 40$.

${ }^{45}$ Asian Development Bank, above n 9.

${ }^{46}$ Ibid.

${ }^{47}$ Hossain and Roy, above n 40 .

48 Ibid.
} 
money. ${ }^{49}$ Corruption in the process of project design may be more fatal than corruption in the process of implementation of the project. There are serious allegations against the ADB in respect to accountability, as observed in the above mentioned report:

\begin{abstract}
No substantive evidence has been found that the local communities and indigenous people or civil society were involved or participated in decision-making. Most of the money was spent against foreign consultants ... Most of the projects documents are not disclosed among public or neither accessible to researchers nor other interested parties from the ADB and GEF [Global Environment Facility]. This gives rise to the perception that $A D B$ and GEF had other intention rather than stated in their policies and project objectives. ${ }^{50}$ (emphasis added).
\end{abstract}

The most unfortunate aspect of the whole process is that Bangladesh now has to repay the loan to the ADB. The experience of the Sundarbans Biodiversity Project must be taken into account in framing future REDD+ projects. The participation of foreign consultants should be kept to minimum. In fact, Bangladesh, having a number of well-established forestry research and educational institutions, arguably does not need any foreign consultant for implementing forest conservation projects. Spending 53 per cent of the project budget for an unnecessary purpose is not acceptable.

There should be a proper mechanism so that forest dependent people can gain tangible benefits from future REDD+ projects. Conservative forest laws, a relic of the colonial legacy, not only created an ideal atmosphere for corruption by local officials but also created the room for more severe corrupt practices by their international collaborators. To ensure conservation of forests, people of least developed counties like Bangladesh must find a way to break this vicious circle of neo-colonialism.

Making the issue more complex, REDD+ projects may also involve the issue of carbon rights, an alien concept in Bangladesh's legal system. This issue, at the same time, may create an opportunity to devise an equitable forest law in developing countries - if not manipulated by vested interests. As the government has ownership of the Sudarbans, it may arguably be said that the government is the sole owner of all property rights and interests including the carbon rights arising from the forest. However, as explained earlier, establishment of the government's absolute ownership over the forests of Bangladesh in the colonial era was problematic from the beginning. Bangladesh should not repeat the same mistake. In devising future carbon rights legal framework the rights of forest-dependent people should be given preference, and their ownership over carbon rights should be specifically recognised.

\title{
Concluding temarks
}

If properly implemented, a REDD+ project may have a positive impact on the Sundarbans and local communities reliant on the forest. However, from the inception to the final implementation, the accountability of relevant local and international actors must be ensured for the success of the project. At the same time, the rights of the local people must be recognised in practical terms. The project must have mechanism to ensure that local people can have tangible benefit from the project. There should be adequate safeguards for upholding integrity in the all stages of implementation. Unlike previously initiated failed projects, the proposed project should ensure full participation of local people.

\footnotetext{
${ }^{49}$ Ibid.

${ }^{50}$ Ibid.
} 